\title{
Well Water Quality Assessment: A Case of Gaba and Zuma Communities, Bwari Area Council, Abuja, Nigeria
}

\section{${ }^{1}$ EZEH, CC; ${ }^{*}{ }^{1}$ UDOURIOH, GA ; ${ }^{2}$ ECHOKE, JC; ${ }^{1}$ MATTHEWS-AMUNE, OC}

\author{
${ }^{I}$ Department of Pure and Applied Chemistry, College of Natural and Applied Sciences, Veritas University, Abuja, Nigeria \\ ${ }^{2}$ Quality Control Department, Federal Capital Territory (FCT) Water Board, Abuja, Nigeria \\ *Corresponding Author Email: gadiurioh@yahoo.com; Tel: +2348062804260.
}

\begin{abstract}
The sixth Sustainable Development Goals (SDGs) underscores the need for clean, accessible water and good sanitation for all as an essential part of the world we live in. However, water scarcity still affects more than $30 \%$ of the world's population. Many communities, especially in Africa, have resorted to substandard and cheaper sources of water for consumption, and hand dug well is one of them. In this study, the physicochemical, biochemical and microbiological assessment of well water samples from Gaba 1, Gaba 11 and Zuma 11 communities in Bwari Area Council, Abuja, Nigeria were carried out as a case study to determine the quality of well water. The American Public Health Association (APHA) standard analytical methods were adopted and results were compared with the World Health Organization (WHO) standards and Nigerian Standard for Drinking Water Quality (NSDWQ). From the results obtained for the physicochemical parameters, turbidity and colour did not meet up with the WHO and NSDWQ standard. Colour ranged from $330 \pm 20 \mathrm{PtCo}$ to $57.60 \pm 14.50 \mathrm{PtCo}$ as against $15 \mathrm{PtCo}$ by WHO and NSDWQ, turbidity ranged from $45.2 \pm 0.2 \mathrm{NTU}$ to $7.19 \pm 0.4 \mathrm{NTU}$ as against $5 \mathrm{NTU}$ by WHO and NSDWQ. Other physicochemical parameters were within WHO and NSDWQ limit. The bacteriological and biochemical results showed the presence of E-coli and other coliforms in all the samples. The total coliforms count for all the wells ranged from $1.55 \times 10^{2}$ to $1.775 \times 10^{2} \mathrm{CFU} / \mathrm{ml}$, indicating a noncompliance to the zero count per $100 \mathrm{ml}$ by WHO. Well water from these communities pose a great health risk to the consumers.
\end{abstract}

\section{DOI: https://dx.doi.org/10.4314/jasem.v24i6.4}

Copyright: Copyright $\left({ }_{0} 2020\right.$ Ezeh et al. This is an open access article distributed under the Creative Commons Attribution License (CCL), which permits unrestricted use, distribution, and reproduction in any medium, provided the original work is properly cited.

Dates: Received: 11 April 2020; Revised: 15 May 2020; Accepted: 05 June 2020

Keywords: Well water, Quality assessment, Physicochemical parameters, Microbiological, WHO.

To date, water scarcity affects more than 30 percent of the global population and is projected to rise beyond this if proper measures are not put in place to curtail it (UNSDG, 2018). Several developing countries within Sub-Saharan Africa, Central Asia, Southern Asia, Eastern Asia and South-Eastern Asia are faced with the worst case scenario (SDG Baseline update, 2017). According to the 2018 United Nations Sustainable Development Goals (UNSDG) report, 71\% of the global population have access to safely managed drinking water services. This invariably implies that 3 in 10 people lack access to safely managed drinking water services globally (Polma, 2018). The percentage is quite low in Sub-Saharan Africa (46 out of 54 African countries) where only $24 \%$ of its population have access to safely managed drinking water services (UNSDG, 2018). Water scarcity, poor water quality and inadequate sanitation negatively impact livelihood choices, food security and educational opportunities for poor families across the world (Sivaranjani et al., 2015; Pal et al., 2018). Millions of people including children die every year from diseases associated with inadequate water supply, sanitation and hygiene. Each day, nearly 1,000 children die due to preventable water and sanitation-related diarrheal diseases (UNICEF, 2018). The scarcity of safe drinking water poses a great danger to public health and wellbeing by exposing people to the risk of water borne diseases such as diarrhoea, dysentery as well as chemical intoxication (Pal et al., 2018). Although various agencies that drive the SDGs have been working to ensure that the future water needs are met globally, the challenges of meeting the water needs in a sustainable manner in Sub-Saharan Africa, especially in some parts of Nigeria are daunting. Seventy-six percent $(76 \%)$ of about 202 Million latest United Nations estimated population in Nigeria, especially in rural areas, lack access to safe drinking water and therefore depend on any easily accessible, cheaper, unimproved, limited and surface water sources such as hand dug well, stream, river, lake, pond and canal as sources of their water for drinking and other domestic purposes (Singh et al., 2015). Vulnerability to water borne diseases such as diarrhoea, cholera, typhoid fever, Hepatitis A and E, fluorosis, salmonellosis, shigellosis, 
leptospirosis and schistomiasis are on the increase (Pal et al., 2018). There is also a high morbidity and mortality rates in the rural areas in Nigeria, especially, among children under five (UNICEF, 2018). Most often Nigerians attribute these dreadful conditions to witches and wizards whereas the eminent causes of the problems are completely neglected. This may be as a result of the limited information with strong evidences available to their disposals.

Gaba and Zuma communities of Bwari Area Council, Abuja, Nigeria, Sub-Saharan Africa are also caught in the web. Gaba and Zuma are semi-urban-rural communities faced with limited supply of water. Most people depend on well water and borehole as their sources of water, but the cost of digging borehole is so high to the extent that well water source becomes the possible alternative. Most of the wells are located at unhygienic areas such as near refuse dumps, pit latrine, suck-away while some are not covered. The anthropogenic activities and poor sanitation around the well reservoirs may make the well water unsafe for use for any purpose let alone human consumption. Over the years, several studies have been conducted on the qualities of different sources of water at different locations in Nigeria (Adediji and Ajibade, 2005; Olorunfemi et al., 2011; Aremu et al., 2011; Ali et al., 2012; Jidauna et al., 2013; Atarhe and Egbuna, 2013; Aboh et al., 2015). But there is scarcely any work on the well water quality in Gaba and Zuma communities, Bwari area council, Abuja, Nigeria. It is believed if the people are confronted with facts and evidence on the quality of water they use on daily basis and the implications, their belief system may be refined. This work therefore assessed the physicochemical, microbiological and biochemical properties of the dug well water samples from Gaba and Zuma communities of Bwari Area Council, Abuja, Nigeria as a case study on the quality of well water in order to inform the consumers accordingly, draw the attention of the relevant authorities to the plight of these communities and advocate with evidences for interventions in order to meet the Sustainable Development Goal six.

\section{MATERIALS AND METHOD}

Materials: The materials used for this work include: spectrophotometer model DR $5000^{\mathrm{TM}}$, TDS/Conductivity Meter (HACH) model 446000.00, Turbidimeter HACH model DR2010, HANA pH meter model IH 98129, Autoclave, Incubator, Thermometer, digital weighing balance, Alkalimetric reagent $\left(\mathrm{H}_{2} \mathrm{SO}_{4}\right.$ and $\left.\mathrm{HCl}\right)$, Methyl orange, Ethylene diamine tetra-acettic acid (EDTA), $\mathrm{K}_{10}$ buffer solution, Erichrome black $\mathrm{T}$ (net solution), Pillow reagents,
Deionized/distilled water, Lactose broth, Eosine Methylene Blue (EMB) Agar, Silver nitrate, Potassium dichromate, Nitric acid, crystal violet, safranin, lugols iodine, kovac's reagent, chloroform, hydrogen peroxide, MR/VP medium, Macon key reagent, Nutrient agar. $100 \mathrm{ml}$ beaker, $250 \mathrm{ml}$ conical flask, $50 \mathrm{ml}$ burette, $1000 \mathrm{ml}$ volumetric flask, McCartney bottles, Durharm's tube, Methylated spirit, $1000 \mathrm{ml}$ measuring cylinder, $100 \mathrm{ml}$ measuring cylinder.

Sample Collection and Preservation: The samples were collected from three different wells in each of the three communities Gaba 1, Gaba 11 and Zuma 11 making it total of nine samples. The water samples for physicochemical analysis were collected from the well by immersion below water level using bucket and dispensed immediately into the labeled sterile borosilicate sample bottles. The temperature of the water was measured in situ. Five hundred milliliter $(500 \mathrm{ml})$ sterile bottles were used in collecting the water samples for bacteriological analysis. These were quickly capped. All the samples were placed in ice box and quickly transported to FCT Water Board quality control lab II where analysis commenced with immediate effect.

Physicochemical Analysis: The following physicochemical parameters: temperature, colour, turbidity, conductivity, $\mathrm{pH}$, total dissolved solids, total hardness, total alkalinity and chloride ions concentration were analyzed following the American Public Health Association standard methods (APHA, 2012). In each case the mean values and standard deviation were calculated as reported in Table 1.

Temperature: Temperature of the water sample was taken in situ. Mercury glass bulb thermometer in degree Celsius was used.100ml of the well water samples were poured into $250 \mathrm{ml}$ beakers. The mercury glass bulb thermometer was immersed in the water in the beaker and the reading was taken after few minutes and recorded in degree Celsius.

Colour: This was determined using spectrophotometer model HACH DR 5000. The cuvette was rinsed with deionized water and machine was initialized. Blank was analyzed using deionized water. The samples were then dispensed into the cuvette and the cuvette was inserted into the sample compartment of the spectrophotometer. Then the reading was taken in line with the APHA and WHO guidelines.

Turbidity test: The turbidity was measured with HACH model DR2010 turbid meter. $10 \mathrm{ml}$ of the samples were dispensed in the cuvette. Then the cuvette was inserted into the turbid meter. The reading 
was taken and recorded in Nephelometric turbidity unit (NTU).

Conductivity: The conductivity of the well water samples were determined using conductivity meter. The probe was rinsed with deionized water. A magnet was dropped into the beaker containing $100 \mathrm{ml}$ of the water sample. Then it was placed on the magnetic stirrer. The temperature of the sample was inputted. The sample was stirred for few seconds and the reading was recorded.

$p H$ : the $\mathrm{pH}$ of the water samples was determined using a calibrated $\mathrm{pH}$ meter. The $\mathrm{pH}$ meter was standardized with buffer $7.100 \mathrm{ml}$ of the well water samples were measured into a small beaker. The probe of $\mathrm{pH}$ meter was rinsed in deionizer water. The probe of $\mathrm{pH}$ meter was carefully inserted into water sample and was allowed to stabilize. Then the reading was taken.

Total Dissolved Solid: TDS was determined using the searchtech conductivity meter. The probe was rinsed with deionized water. A magnet was dropped into the beaker containing $100 \mathrm{ml}$ of the water sample. Then it was placed on the magnetic stirrer. The temperature of the sample was inputted. The sample was stirred for few seconds. The reading was recorded.

Total hardness: $100 \mathrm{ml}$ of well water sample was measured and dispensed into a $250 \mathrm{ml}$ conical flask. The burette was rinsed with deionized water and then with EDTA reagent. The burette was filled with the EDTA reagent. 20 drops of $\mathrm{K}_{10}$ buffer solution was added into the conical flask and 5 drops of net solution (Erichrome black T) was added. 0.04N EDTA was titrated against the solution until there was a change in the colour from violet to blue which indicated the endpoint. The reading on the burette determines the volume of $0.04 \mathrm{~N}$ EDTA used.

Total alkalinity: $100 \mathrm{ml}$ of well water samples were measured into $250 \mathrm{ml}$ conical flask. 2 drops of methylorange was added into the water samples. The $50 \mathrm{ml}$ burette was rinsed and filled with the alkalimetric reagent $\left(\mathrm{H}_{2} \mathrm{SO}_{4}\right.$ and $\left.\mathrm{HCl}\right)$ and was titrated against the sample solution. Yellow - orange colouration at end point was observed. The titer value was recorded.

Chloride ion: $100 \mathrm{ml}$ of well water samples were measured into a conical flask. 5 drops of potassium dichromate $\left(\mathrm{K}_{2} \mathrm{Cr}_{2} \mathrm{O}_{7}\right)$ was added as an indicator and silver nitrate as the titrant. Near the end point, silver ion reacts with chromate ion to form silver chromate which indicates the end points changing from yellow to brick red.
Bacterial Characterization/Biochemical Analysis: Holt et al. (1994) method was used for the characterization of bacterial isolates. Isolates were observed for growth and morphological characteristics after gram staining. Fecal coliform was enumerated using eosin methylene blue agar, while heterotrophic plate count was done using nutrient agar. The pour plate technic was used. A 1:10 dilution of sample was carried out for all plating. $0.1 \mathrm{ml}$ inoculum size was pipetted from the selected dilution and inoculated on freshly prepared eosin methylene blue agar and nutrient agar and swirled to mix evenly. The plates were incubated overnight and colonies counted using colony counter. Results were recorded accordingly.

Triple sugar iron test: This was used to assess the ability of the organisms to utilize glucose, fructose and lactose. Pure culture from slant was incubated in nutrient broth. Inoculums were picked using an inoculating needle and were stabbed down through the butt, and then the needle pulled out and streaked over the entire surface of the TSI slant. The tubes were then placed in the rack and Incubated at $37^{\circ} \mathrm{C}$ for 24 hours. Results were taken and recorded for complete fermentation or production of hydrogen sulphide.

Gram stain: Samples from broth were smeared on glass slide using sterile water. This was done aseptically to make a thin film; air dried and passed over flame through the reserve side of slide to fix. After cooling, the slides were then flooded with crystal violet for 60 seconds. This was then drained off and washed with Gram's iodine and left for 1 minute, drained and washed under tap gently. These were then decolourized with ethanol. Slides were washed under tap again and finally counterstained with safranin for 30 seconds, drained and dried. The covered slides were examined under the oil immersion of the microscope and observations were recorded.

Methyl red test: MR-VP broth was prepared by dissolving $3.48 \mathrm{~g}$ of MR-VP in $200 \mathrm{ml}$ of deionized water. The mixture was sterilized in the autoclave at $121^{\circ} \mathrm{C}$ for 15 minutes. The broth after cooling was inoculated with two loops full of respective bacterial culture. Labeling was done appropriately and the test tubes were incubated at $37^{\circ} \mathrm{C}$ for 48 hours. Five drops of methyl red indicator was added in the incubated tubes. The results were observed and recorded.

Catalase test: A sterile inoculating loop was used to collect a small amount of organism from a wellisolated 24hour colony and was placed onto a microscope slide. $3 \%$ hydrogen peroxide was used to emulsify samples on a glass slide. Frothing or foaming 
was recorded as a positive test. Reaction is given as $2 \mathrm{H}_{2} \mathrm{O}_{2} \rightarrow 2 \mathrm{H}_{2} \mathrm{O}+\mathrm{O}_{2}$.

Urease test: This was used to assess the ability of organisms to hydrolyze urea (organic nitrogen source) to ammonia and carbon dioxide using the enzyme urease. Christensen Urea agar was used for this test. This was prepared according to specification and autoclaved. It was dispensed into sterile test tubes as slants. Samples were inoculated by stabbing and streaking the entire surface. The tubes were then incubated for 72 hours. These were then examined and results recorded.

Citrate test: This test assesses the organism on its ability to utilize citrate as sole source of carbon. Simmons citrate agar was used for this test. This was prepared according to specification. It was dispensed into Bijou bottles and allowed to set in a slant position. Pure cultures from slants were gently inoculated into nutrient broth. These were then inoculated with organisms from nutrient broth by stabbing and then streaking the entire surface of slant and incubated for 72 hours at $35^{\circ} \mathrm{C}$. The bottles were examined for colour change from green to blue. Growth with blue coloration is positive. These were then recorded.

Starch hydrolysis: Starch agar was used for this test (nutrient agar $+1 \%$ soluble starch). The plates were inoculated and incubated at $37^{\circ} \mathrm{C}$ for 3 days. After incubation, the plates were flooded with Gram's iodine.

Indole test: The indole test assesses the ability of an organism to hydrolyze the amino acid tryptophan to produce indole. Kovac's reagent was used for this test. $5 \mathrm{ml}$ of samples were pipetted from culture broth into sterile test tubes. The broth was prepared by inoculating tryptone broth with inoculums from slants and incubated (Tryptone broth was prepared by dissolving $10 \mathrm{~g}$ of tryptone in 1 liter of distilled water). This was dispensed in appropriate number of test tubes and sterilized. $2 \mathrm{ml}$ of $99 \%$ chloroform was then added to each sample tube and shaken. Then $2 \mathrm{ml}$ of Kovac's reagent was added and left to stand for 20 minutes. Formation of red rings at the surface of medium gave an indication that indole was produced. These were recorded as positive for indole production.

Bacteriological Presumptive and Confirmatory Tests Media Preparation: All microbiological media (The Nutrient agar, Eosin Methylene Blue agar, Lactose broth) were all prepared according to manufacturer's specifications and instructions and were sterilized using autoclave $121^{\circ} \mathrm{C}$ for 15 minutes. $21 \mathrm{~g}$ of DEV lactose-peptone-Bouillon broth was weighed and dissolved in $600 \mathrm{ml}$ of distilled water. A cuvette was used to measure out $10 \mathrm{ml}$ of lactose broth into multiple McCartney bottles. Durham's tubes were inserted into each bottle inverted. The colour at that point was purple. The lactose broth was sterilized in an autoclave at $121^{\circ} \mathrm{C}$ for $15 \mathrm{mins}$ after which the bottles were stored in the refrigerator until it was needed.

Viable Count: Total aerobic Count in all water samples collected were enumerated after being serially diluted with the dilution factor of 100 in the ratio of 1:100 and the aliquot was inoculated into nutrient agar, properly mixed in a sterile Petri dish using the pour plate method.

Total Coliform Count: The multiple tube fermentation technique as described standard methods for water and waste water analysis was used (APHA, 2012). 10ml of water samples was added to $10 \mathrm{ml}$ of double strength Lactose broth in sterile McCartney bottles. The McCartney bottles were incubated at $37^{\circ} \mathrm{C}$ for 24 hours after which they were all examined for production of acid and gas as indicated by trapping of gas in the Durham's tube in the fermentation bottles and production of acid as indicated by the change in colouration of the medium from purple to yellow. Sterile de-ionized water was used as a control. Total coliform count was obtained by the most probable number (MPN) of coliform per $100 \mathrm{ml}$ of water sample by making reference to the MPN table in standard methods (APHA, 2012). Positive tubes that showed production of acid and/ or gas were plated onto eosin methylene blue (EMB) agar plates and incubated for 24 hours. Plates showing growth were noted and colonies transferred to lactose broth and incubated at $44.5^{\circ} \mathrm{C}$ for 24 hours to ascertain presence of feacal coliforms for the completed test. The confirmed phases and completed test were done using EMB and lactose broth incorporated with bromocresol purple indicator respectively.

Presumptive Test: To determine the MPN, six sets of ten tubes containing the same growth media and Durham's tubes were prepared. Each was inoculated with a measured amount of water sample i.e. water sample from well -A, B, C, D, E, F (10 bottles of 10ml for each sample), ensuring a spirit lamp was lit to ensure a sterile environment. Talking was avoided so as not to contaminate samples. The inoculated bottles were incubated for 24 hours at $37^{\circ} \mathrm{C}$. The bottles were examined for gas and acid production. Confirmatory Test: All positive presumptive test bottles were collected. A sterilized wire loop was used to streak from the presumptive bottles onto three well labeled Eosin Methylene Blue (EMB) agar plate, then it was 
incubated for 24 hours at $21^{\circ} \mathrm{C}$. The observation was recorded.

\section{RESULTS AND DISCUSSION}

The results of the physicochemical parameters are presented in Table 1 alongside the WHO and NSDWQ standards. Figure 1 shows the comparison of the colour, total dissolved solids (TDS) and electrical conductivity of the well water from the three communities with WHO and NSDWQ standards. From the result as shown in Figure 1, the colour of all the samples did not conform to the WHO and NSDWQ standards. Electrical conductivity and TDS are within the WHO and NSDWQ guidelines. However, the electrical conductivity of the Zuma 11 and Gaba 11 wells were quite low. The non-conformity of the colour with standards may be due to the presence of complex organic molecules derived from vegetable (humic) matter such as peat, leaves, branches etc. (Malakootian and Fatehizadeh, 2010). Water is supposed to be colourless, hence water with high degree of colour as shown in the results is not suitable for domestic purposes let alone consumption, except it is properly treated (Malakootian and Fatehizadeh, 2010).

\begin{tabular}{lllllll}
\multicolumn{7}{c}{ Table 1: Result on Physicochemical Analysis } \\
\hline S/N & $\begin{array}{l}\text { Water Quality } \\
\text { Parameter }\end{array}$ & $\begin{array}{l}\text { WHO } \\
\text { Standard }\end{array}$ & $\begin{array}{l}\text { NSDWQ } \\
\text { standard }\end{array}$ & $\begin{array}{l}\text { GABA I } \\
\text { Well water }\end{array}$ & $\begin{array}{l}\text { GABA II } \\
\text { Well water }\end{array}$ & $\begin{array}{l}\text { ZUMA II } \\
\text { Well water }\end{array}$ \\
\hline 1 & Colour $(\mathrm{PtCo})$ & $<15$ & 15 & $59.5 \pm 14.50$ & $57 \pm 6.00$ & $330 \pm 20.00$ \\
2 & TDS $(\mathrm{mg} / \mathrm{l})$ & $<1500$ & - & $1337 \pm 12.0$ & $382 \pm 6.0$ & $312.5 \pm 56.51$ \\
3 & Conductivity $\left(\mu \mathrm{s} / \mathrm{cm}^{3}\right)$ & $<1250$ & - & $420 \pm 6.0$ & $104.5 \pm 0.7$ & $80.8 \pm 0.2$ \\
4 & Turbidity $(\mathrm{NTU})$ & $<5$ & 5 & $8.36 \pm 0.08$ & $7.19 \pm 0.4$ & $45.2 \pm 0.2$ \\
5 & pH(Ph units) & $6.5-8.5$ & $6.5-8.5$ & $6.87 \pm 0.1$ & $6.86 \pm 0.07$ & $6.9 \pm 0.03$ \\
6 & Temperature $\left({ }^{\circ} \mathrm{c}\right)$ & 29 & ambient & $27.5 \pm 0.5$ & $28 \pm 0.00$ & $29 \pm 0.00$ \\
7 & Total Alkalinity $(\mathrm{mg} / \mathrm{L})$ & $<250$ & 250 & $63 \pm 9.00$ & $50 \pm 2.00$ & $49 \pm 1.00$ \\
7 & Total Hardness $(\mathrm{mg} / \mathrm{l})$ & $<500$ & 150 & $78 \pm 18.00$ & $56 \pm 4.00$ & $74 \pm 4.00$ \\
9 & Chloride ion $(\mathrm{mg} / \mathrm{L})$ & $<250$ & 250 & $45.44 \pm 22.7$ & $19.17 \pm 4.97$ & $19.17 \pm 2.13$ \\
\hline
\end{tabular}

Figure 1 shows the comparison of the turbidity, $\mathrm{pH}$ and temperature with WHO and NSDWQ. The well water from Zuma 11 has the highest turbidity of $45.2 \pm 0.2 \mathrm{NTU}$, followed by Gaba 1 and Gaba 2 with $8.36 \pm 0.08 \mathrm{NTU}$ and $7.19 \pm 0.4 \mathrm{NTU}$ respectively. These values are against the $5 \mathrm{NTU}$ maximum turbidity limit by WHO and NSDWQ (Table 1). The turbidity parameter did not conform to the WHO and NSDWQ standards. Turbidity in a way is the cloudiness of water that is caused by suspended particles. The increase in turbidity in the wells means that there is increased cloudiness.

This is attributed to suspended particles of sand, silt and clay within the vicinity. Colour and turbidity are very important physicochemical parameters for water quality. Turbidity can lower the aesthetic acceptability of drinking water. It can occur as a result of inorganic particles released by weathering of rocks, soils and clay; human and livestock waste; biological growth such as algae in source water and natural organic matter like decomposing plant material (WHOIPCS, 1996). Therefore this high turbidity indicates the presence of hazardous chemical and microbial contaminants. The nonconformance of turbidity of the well water to standards posits great danger (CAWST, 2009). Previous studies from other locations of the country equally recorded high turbidity range (Adediji and Ajibade, 2005; Ali et al., 2012; Jidauna et al., 2013).

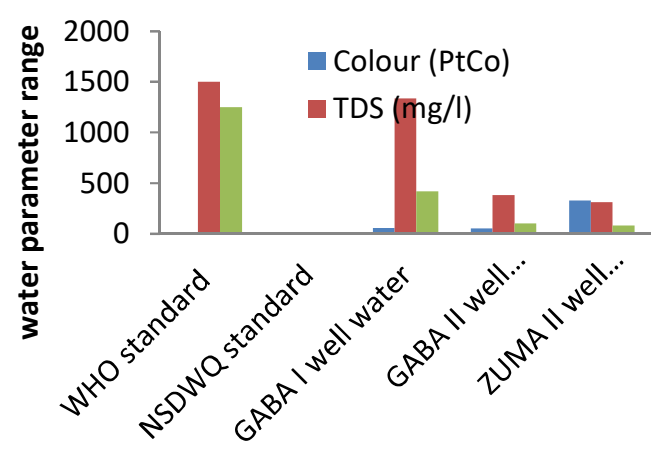

Fig. 1: Comparison of colour, TDS and Conductivity of the well water with WHO and NSDWQ standard values

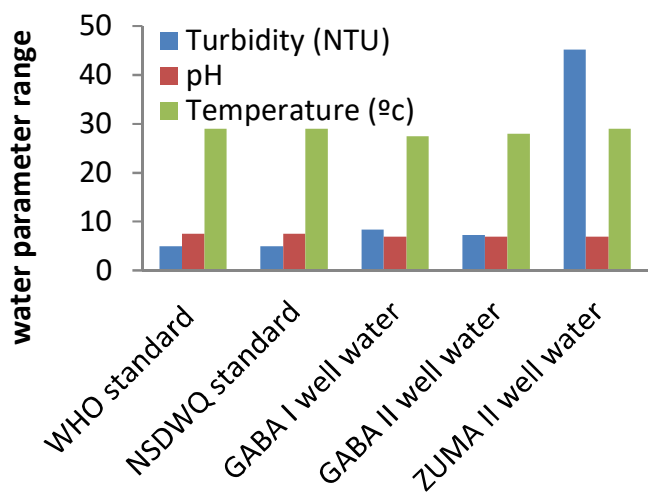

Fig.2: Comparison of Turbidity, $\mathrm{pH}$ and Temperature of the well water with WHO and NSDWQ standard values 


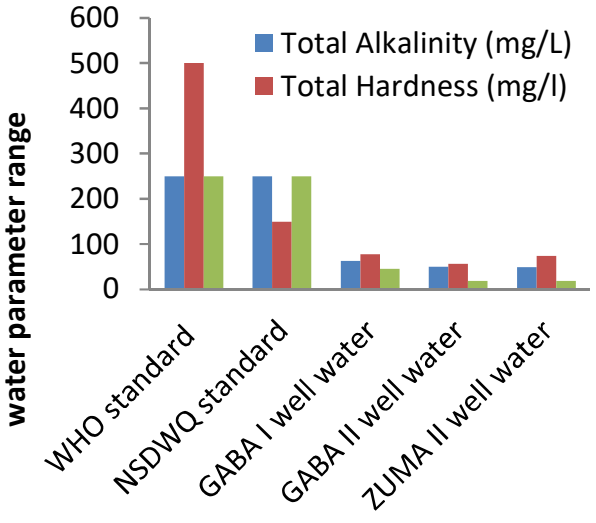

Fig. 3: Comparison of Total alkalinity, Total hardness and Chloride ion conc. of the well water with WHO and NSDWQ standard values

Figure 3 shows the comparison of the total alkalinity, total hardness and chloride ion concentration of the well water samples with WHO and NSDWQ guidelines. These three parameters are in line with the standards. However, it is worthy of note that only the physicochemical parameters cannot give the full assessment of the quality of water. According to the report from the Centre for Affordable Water and Sanitation Technology, Alberta, Canada, "when considering drinking water quality, in most cases microbiological contamination is the main concern since it is responsible for the majority of illnesses and deaths related to drinking unsafe water" (CAWST, 2009). The results of the microbiological assessment of the well water samples are therefore presented in Tables 2 and 3. Table 2 shows the results for the bacterial characterization and biochemical tests while
Table 3 shows the bacterial confirmatory test results. From the results, the bacteriological counts in all the well water samples showed massive contamination with bacteria. All samples were positive for the presumptive coliform tests. It was observed that all samples had the most probable number (MPN) bacterial index of $>23.0$ for the $10 \mathrm{ml}$ inoculum sample variant used (Table 3). This completely deviates from the WHO recommendation (WHO, 2006). It suffices to also infer that the unaesthetic and unsanitary condition of these wells have contributed to the high population of coliforms and other bacterial contaminants. The most probable number (MPN) per $100 \mathrm{ml}$ obtained for the well water samples $(>23.0)$ certainly exceeds the standard limit recommended by WHO and Nigerian standards for drinking water quality. This is indicative of contamination by pathogenic organisms. Fecal contaminants were isolated which is an indication that the well water samples are not good for any domestic usage. This result is similar to that obtained by Idowu et al. (2011) in their study of the Bacteriological analysis of well water samples in Sagamu where their results showed high contamination by Escherichia coli, Klebsiella spp and Salmonella typhi and other coliform contaminants. Some typical isolates found in the works of Aboh et al. (2015) and Aturamu (2012) were also identified. It suffices to also infer that the unaesthetic and unsanitary condition of these wells have contributed to the high population of coliforms and other bacterial contaminants. The most probable number (MPN) per $100 \mathrm{ml}$ obtained for the well water samples $(>23.0)$ certainly exceeds the standard limit recommended by WHO and Nigerian standards for drinking water quality.

Table 2: Biochemical / Bacterial Characterization Test Result

\begin{tabular}{|c|c|c|c|c|c|c|c|c|c|c|c|}
\hline$\frac{\mathscr{c}}{\bar{E}}$ & 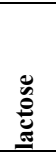 & 咅 & $\bar{\Omega}$ & $\mathbf{I}$ & 总 & 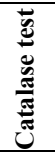 & 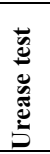 & 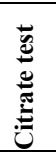 & 를 & 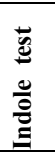 & 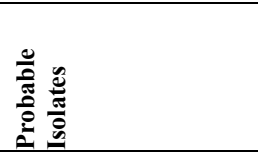 \\
\hline A & $+\mathrm{ve}$ & $\begin{array}{l}\text { Mixed culture: } \\
\mathrm{g}+\text { ve cocci and } \\
\text { g-ve rods }\end{array}$ & $\begin{array}{l}\text { Acid \& } \\
\text { gas }\end{array}$ & -ve & $+\mathrm{ve}$ & $+\mathrm{ve}$ & + ve & $-\mathrm{ve}$ & $+\mathrm{ve}$ & $+\mathrm{ve}$ & $\begin{array}{l}\text { Escherichia coli, } \\
\text { Klebsiella, Proteus }\end{array}$ \\
\hline B & + ve & $\begin{array}{l}\text { Mixed culture: } \\
\text { g+ve cocci and } \\
\text { g-ve rods }\end{array}$ & $\begin{array}{l}\text { Acid \& } \\
\text { gas }\end{array}$ & + ve & $+\mathrm{ve}$ & -ve & + ve & -ve & + ve & + ve & $\begin{array}{l}\text { Escherichia coli, } \\
\text { Streptococcus, Proteus } \\
\text { and Klebsiella }\end{array}$ \\
\hline $\mathrm{C}$ & + ve & Gram -ve rods & $\begin{array}{l}\text { Acid \& } \\
\text { gas }\end{array}$ & -ve & + ve & -ve & + ve & $+\mathrm{ve}$ & $+\mathrm{ve}$ & -ve & $\begin{array}{l}\text { Salmonella, Klebsiella } \\
\text { and Pseudomonas } \\
\text { aeruginosa }\end{array}$ \\
\hline $\mathrm{D}$ & $+\mathrm{ve}$ & g-ve rods & $\begin{array}{l}\text { Acid \& } \\
\text { gas }\end{array}$ & -ve & + ve & $-\mathrm{ve}$ & + ve & $+\mathrm{ve}$ & + ve & + ve & Klebsiella, E. coli \\
\hline $\mathrm{E}$ & + ve & g-ve rods & $\begin{array}{l}\text { Acid \& } \\
\text { gas }\end{array}$ & -ve & $+\mathrm{ve}$ & + ve & + ve & $+\mathrm{ve}$ & + ve & + ve & E. coli, Klebsiella \\
\hline $\mathrm{F}$ & $+\mathrm{ve}$ & $\begin{array}{l}\text { g-ve rods or g+ } \\
\text { cocci }\end{array}$ & $\begin{array}{l}\text { Acid \& } \\
\text { gas }\end{array}$ & -ve & $+\mathrm{ve}$ & $-\mathrm{ve}$ & + ve & + ve & + ve & $+\mathrm{ve}$ & $\begin{array}{l}\text { Entrobacter, E. coli, } \\
\text { Streptococcus and } \\
\text { Klebsiella }\end{array}$ \\
\hline
\end{tabular}


Table 3: Bacteriological Test Result

\begin{tabular}{llllllllll}
\hline & & & & & &
\end{tabular}

This is indicative of contamination by pathogenic organisms. Fecal contaminants were isolated which is an indication that the well water samples are not good for any domestic usage. This result is similar to that obtained by Idowu et al. (2011) in their study of the Bacteriological analysis of well water samples in Sagamu where their results showed high contamination by Escherichia coli, Klebsiella spp and Salmonella typhi and other coliform contaminants. Some typical isolates found in the works of Aboh et al. (2015) and Aturamu (2012) were also identified

It suffices to also infer that the unaesthetic and unsanitary condition of these wells have contributed to the high population of coliforms and other bacterial contaminants. The most probable number (MPN) per $100 \mathrm{ml}$ obtained for the well water samples $(>23.0)$ certainly exceeds the standard limit recommended by WHO and Nigerian standards for drinking water quality. This is indicative of contamination by pathogenic organisms. Fecal contaminants were isolated which is an indication that the well water samples are not good for any domestic usage. This result is similar to that obtained by Idowu et al. (2011) in their study of the Bacteriological analysis of well water samples in Sagamu where their results showed high contamination by Escherichia coli, Klebsiella spp and Salmonella typhi and other coliform contaminants. Some typical isolates found in the works of Aboh et al. (2015) and Aturamu (2012) were also identified

Conclusion: It is important to judge the safety of water by taking the physicochemical, biochemical and microbiological properties into consideration. In most cases microbiological contamination is the main concern since it is responsible for the majority of illnesses and deaths related to drinking unsafe water. In this study, turbidity and colour of all the water samples did not conform to WHO standard. This exceedance of the turbidity level suggests that the consumers of the water are at high risk of pathogenic and enteric diseases. The bacteriological and biochemical results showed the presence of E-coli and other coliforms in all the samples. The total coli form count for all the wells ranged from $1.55 \times 10^{2}$ to $1.775 \times 10^{2} \mathrm{CFU} / \mathrm{ml}$ and hence does not conform to the zero count per $100 \mathrm{ml}$ by WHO standard. Well water from these communities is likely to pose a great health risk to the consumers.

Acknowledgements: The authors of this work are glad to acknowledge the Chief Technologist, of Chemistry Department, Veritas University Abuja, Mr. Chris Uwadiale for his assistance during the laboratory analysis. We thank the management and staff of Federal Capital Territory (FCT) Water Board, Abuja, Nigeria for the permission to carry out part of the analyses in their laboratory. This work was selffunded by the authors.

\section{REFERENCES}

Aboh, EA; Giwa, FJ; Giwa, A (2015) Microbiological assessment of well waters in Samaru, Zaria, Kaduna, State, Nigeria; Annals Afr. Med. 14(1): 32-38.

Adediji, A; Ajibade, LT (2005) Quality of Well Water in Ede Area, Southwestern Nigeria; J. Hum. Ecol. 17(3): 223-228.

Ali, ZN; Imam, MM; Abdulkadir, FM (2012) Physicochemical and bacteriological analysis of well water in Zango-Abattoir KadunaNigeria. Nig. J. Chem. Res. 17(1): 16-22.

American Public Health Association (APHA) (2012) standard methods for the examination of water and wastewater, (22 ${ }^{\text {nd }}$ Ed.). American Public Health Assiociation: Washington. Section 1000-3000.

Aremu, MO; Ozonyia, GN; Ikokoh, PP (2011) Physicochemical properties of well, borehole and stream waters in Kubwa, Bwari Area Council, FCT, Nigeria. Elect. J. Environ. Agric. Food Chem. 10(6): 2296-2304. 
Atarhe, DO; Egbuna, CK (2013) Physicochemical Assessment of Groundwater Quality in Akure, South-Western Nigeria. J. Civ. Eng. and Urbanism, 3(1): 25-28.

Aturamu, AO (2012) Physical, chemical and bacterial analyses of groundwater in Ikere Township, southwestern Nigeria. Int. J. Sci. Technol. 2(5): 301-308.

Auta, KI; Mohammed, SSD; Abubakar, M (2017) Assessment of Bacteriological Quality of Well Water Around Dogon Dawa District in Birnin Gwari Local Government, Kaduna State. Sci. World J. 12 (4): 38-42.

Centre for Affordable Water and Sanitation Technology (CAWST) (2009) Introduction to Drinking Water Quality Testing: In CAWST Training Manual, Calgary, Alberta, Canada

Holt, IG; Krieg, NR; Sneath, PHA; Staley, IT; Williams, ST (1994) Bergey's Manual of Determinative Bacteriology, (9th Ed.) Baltimore: Williams \& Wilkins.

Idowu, AO; Oluremi, BB; Odubawo, KM (2011) Bacteriological analysis of well water samples in Sagamu. Afr. J. Clinic. Exp. Micro. 12(2): 86- 91.

Jidauna, GG; Dabi, DD; Saidu, JB; Abaje, B; Ndabula, C (2013) Assessment of Well Water Quality in Selected Location in Jos, Plateau State, Nigeria; Int. J. Marine, Atm. Earth Sci. 1(1): $38-46$

Leininger, DJ; Roberson, JR; Elvinger, F (2001) Use of eosin methylene blue agar to differentiate Escherichia coli from other gram-negative mastitis pathogens. J. Vet. Diag. Invest. 13(3):273-275.

Malakootian, M; Fatehizadeh, A (2010) Color Removal from water by coagulation/caustic soda and lime; Iran. J. Environ. Health Sci. Eng. 7(3): 267-272

Nigerian Standard for Drinking Water Quality (NSDWQ) (2007) ICS 13.060.20, Nigerian Industrial Standard NIS 554: 2007

Olorunfemi, AO; Salahudeen, KS; Adesiyan, TA (2011) Ground water quality in Ejigbo town and Environs, southwestern Nigeria. Ife $J$. Sci., 13(1): 111-119.
Pal, M; Ayele, Y; Hadush, M; Panigrahi, S; Jadhav, VJ (2018) Public health hazards due to unsafe drinking water. Air Water Borne Dis, 7(1000138), 2.

Polman, P (2018) Scale and Speed Needed to Make Water, Sanitation and Hygiene a Reality for all: SDG Perspective. Retrieved from www.un.org on September 15, 2019

Singh, S; Raju, NJ; Ramakrishna, C (2015) Evaluation of groundwater quality and its suitability for domestic and irrigation use in parts of the Chandauli-Varanasi region, Uttar Pradesh, India. J. Water Res. Protection, 7(7): 572-587

Sivaranjani, S; Rakshit, A; Singh, S (2015) Water Quality Assessment with Water Quality Indices. Int. J. Bio. Sci. 2(2): 85-94.

Sustainable Development Goal (SDG) (2017) Baseline Report on Progress on Drinking Water, Sanitation and Hygiene. Retrieved from www.un.org on September 15, 2019

UNICEF (2018) Report on Water, Sanitation and Hygiene. Retrieved from www.unicef.org on September 13, 2019

United Nations (UN) (2018) Sustainable Development Goals (SDG) Report. Retrieved from www.un.org on September 15, 2019

WHO (2006) Guidelines for drinking water quality: Recommendations $\left(3^{\text {rd }}\right)$, WHO Genova

WHO (2011) World Health Organization guidelines for drinking water quality World Health Organization \& International Programme on Chemical Safety (WHOIPCS) (1996) Guidelines for drinkingwater quality, Health criteria and other supporting information, (2nd Ed.), Vol 2.

Yates, MV (2016). Drinking Water Microbiology. In Manual of Environmental Microbiology, $\left(4^{\text {th }}\right.$ Ed.) American Society of Microbiology, pp. 31 .

Zamxaka, M; Pironcheva, G; Muyima, N (2004) Microbiological and Physicochemical assessment of the quality of domestic water sources in selected rural communities of the Eastern Cape Province, South Africa. Water $S A, 30(3): 333-340$. 